\title{
Structure of the Phytoplankton in a Water Supply System in the State of Pernambuco - Brazil
}

\author{
Ariadne do Nascimento Moura ${ }^{1 *}$, Ênio Wocyli Dantas ${ }^{1}$ and Maria do Carmo Bittencourt- \\ Oliveira $^{2}$ \\ ${ }^{I}$ Departamento de Biologia; Universidade Federal Rural de Pernambuco; Rua Dom Manoel de Medeiros, s/n; Dois \\ Irmãos; ariadne@db.ufrpe.br; 51171-900; Recife - PE - Brasil. ${ }^{2}$ Departamento de Ciências Biológicas; \\ Universidade de São Paulo; Escola Superior de Agricultura Luis de Queiroz; 13418-900; Piracicaba - SP - Brasil
}

\begin{abstract}
The aim of this work was to study the phytoplankton community composition at limnetic environment in Pernambuco, Brazil. Samplings were carried out from April/2001 to March/2002. Samples to analyses the biotic variables were taken using a recipient with a large overture, at the subsurface and with a Van Dorn bottle at the bottom. The rainfall data were recorded and the water transparency was used to calculate the light attenuation coefficient, photic zone and the determination of trophic state index. The concentrations of total phosphorus and total nitrogen were determined in a typical dry and rainy month. Equitability, also the, similarity and diversity indexes and the densities and correlation of total densities among depths were calculated. Forty-five taxa were identified in Chlorophyta (21spp), Cyanophyta (17spp) and Bacillariophyta (7spp), while flagellates were quantified in groups without identification. Cyanophyta presented highest diversity at both the depths and Planktothrix agardhii was the highest density species. Significant differences were not observed between subsurface and bottom densities. Results showed that the reservoir was eutrophicated and presented high densities of Cyanophyta.
\end{abstract}

Key words: Structure, phytoplankton, water supply system, Brazil

\section{INTRODUCTION}

Major taxonomic algal groups have planktonic species in the continental water bodies. The predominance of a particular group is generally related to the environmental conditions, as nutrient concentrations, geographical localization and morphology of these ecosystems. Factors such as depth, associated with temperature, winds and light penetration are examples of the environmental variables which may influence the phytoplanktonic structure (Reynolds, 1984).The knowledge of the phytoplankton dynamics is relevant because temporal and spatial fluctuations in its composition and biomass may be efficient

* Author for correspondence indicators of natural or antropic alterations in the aquatic ecosystems. Besides, the short term generation of algae (hours or days) makes possible the comprehension of important processes, as for example, the ecological succession and the community becomes useful as a model for a better understanding of other communities (Harris, 1986; Sommer, 1989) and the ecosystems in general (Reynolds, 1997).

In the freshwater environments, qualitative and/or quantitative alterations in the structure of the phytoplanktonic community may have an important meaning for various components of the ecosystem and turn water inappropriate for its several uses. Phytoplankton and zooplankton communities structures are results of the growth, 
reproduction, competition, predation pressure, associated with environmental physical and chemical conditions and nutrients or food availability. Their populations are potential as indicators of changes in trophic-dynamic conditions in aquatic environment (Blancher, 1984; De Bernardi, 1984).Therefore, the knowledge about equitability, richness and similarities in the phytoplanktonic communities is an important implement to characterize and type a lake. Examples of such applications are attempted to associate species composition to lakes trophic state based on the diversity and other indexes (Kalff and Knoechel, 1978).

In recent years, studies on reservoirs, have generally dealt with the structural and behavioral compositions of the phytoplanktonic community, with focus on taxonomic surveys and ecological studies. In Brazil, most of the studies on reservoirs have carried out in the South and Southeast regions (i.e. Giani and Pinto Coelho, 1986; Calijuri et al., 1999; Beyruth, 2000; Calijuri and Dos Santos, 2001, Figueredo and Giani, 2001; Calijuri et al., 2002; Marinho and Huszar, 2002). Most of these are about seasonal and nictemeral variations and only a few are about short term periods.

Chellapa (1990) analyzed phytoplankton composition, biomass and the production in the reservoir of Jundiaí-RN at the Northeast, Brazil. Chellapa et al. (1998) studied phytoplankton from Engenho Armando Ribeiro Gonçalves ReservoirRN (Brazil). Chellapa and Costa (2003) discussed the ecology and the dominance of cyanobacteria in an annual cycle on the eutrophic reservoir Gargalheiras - RN (Brazil). Research on reservoirs started during the 90's in Pernambuco, especially when contaminated water with microcystin was used on the patients under Hemodialisis treatment in Caruaru (Azevedo, 1996, Jochimsen et al, 1998; Bittencourt-Oliveira and Molica, 2003). Bouvy et al. (2000) analyzed the occurrence and dominance of Cylindrospermopsis genus in 39 reservoirs in 1998. Bouvy et al. (2001) reported the dynamics of the Cylindrospermopsis raciborskii cyanobacteria population at the Ingazeira Reservoir where they found a relation between the increase of the nutrient content and the dominance of this species. Falcão et al. (2002) studied planktonic microalgae diversity in 64 reservoirs situated in three phytogeographical zones of the State; "Mata", "Agreste" and "Sertão". Bouvy et al. (2003) carried out a two-year study (1998 -
2000) in the Tapacurá reservoir, relating physical, chemical and biological characteristics of the environment to the consequences of El Niño in 1997.

Considering the importance of phytoplanktonic studies on lentic ecosystems since these organisms have been the base of the trophic food web and an important factor to the public health, the present study aimed to contribute to better understanding of the phytoplanktonic structure in a drinking water supply.

\section{MATERIAL AND METHODS}

Carpina Reservoir is located in the district of Carpina $\left(8^{\circ} 1\right.$ '27'S $\left.36^{\circ} 8^{\prime} 27^{\prime \prime} \mathrm{W}\right)$ in the state of Pernambuco, Brazil. The Carpina reservoir is important for the irrigation and fishing along the watershed. This reservoir has high accumulation capacity $\left(2.7 \times 10^{5} \mathrm{~m}^{3}\right)$ and comprises $6.600 \mathrm{Km}^{2}$ on the hydrographic basin. Based on rainfall data, this area is climatologically characterized by a dry and a rainy period. According to historical averages, rainy period is between March and August with lower rainfall in August (82 $\mathrm{mm}$ ) and highest rainfall in June $(177 \mathrm{~mm})$ while dry period is between September and February with lowest pluviometric indexes in November (18mm) (INMET - National Institute of Meteorology).

Concerning abiotic variables, water samples were taken at the subsurface (monthly) at a single station situated in the pelagic zone near the reservoir dam. Depth was measured using an ecobatimeter (Plastino model Echotest) and water transparency was obtained with a Secchi disk with $25 \mathrm{~cm}$ diameter. The determination of photic zone $\left(\mathrm{Z}_{\mathrm{DS}}\right)$ was a result of Secchi depth with constant 2.7 (Margalef, 1983); the light attenuation coefficient (K-m) was calculated according to Poole and Atkins (1929), and $\mathrm{pH}$ with a potentiometer. Total nitrogen ( $\mu$ g.NT. $\left.\mathrm{L}^{-1}\right)$ and total phosphorus ( $\mu \mathrm{g} . \mathrm{PT} . \mathrm{L}^{-1}$ ) levels were determined by the method of Valderrama (1981). The trophic state index (TSI) of the Carpina Reservoir was calculated according to Secchi disk based on Carlson (1977).

The samples were collected from the subsurface using a recipient with a large overture and in the bottom with a Van Dorn bottle and fixed in situ with Lugol's solution. Algae were identified as species or as the highest possible taxonomic 
resolution using specific literature (Round, Crawford and Mann, 1990; Sant'Anna, 1984; Komarék, 1983; Komárek and Anagnostidis, 1999; Komárek and Anagnostidis, 2005). Algae were quantified by the Utermöhl (1958), using a Zeiss Axiovert $135 \mathrm{M}$ inverted optical microscope. Counting was performed in transect fields and the results were expressed in individuals (cells, filaments, colonies and coenobiums) per liter.

Similarity was calculated by the Index of Sørensen (1948), expressed as following: the closer was $S$ from 1 the higher was the community similarity and the closer was $\mathrm{S}$ from 0 , the lower was similarity. Absence and presence of the species were used to calculate the Similarity Index between the depths of subsurface and bottom in each month. The Specific Diversity Index was calculated based on Shannon $\left(\mathrm{H}^{\prime}\right)$ (Shannon, 1948). Equitability (J') was calculated from Shannon Index (H') (Shannon, 1948). Matrix correlation (r) was calculated among total densities considering the depths $(\mathrm{p}<0.05)$. Non-parametric variables were analyzed using Spearman's correlation coefficient $(\mathrm{rs})(\mathrm{p}<0.05)$ in the BioEstat 3.0 software (Ayres et al., 2003).

\section{RESULTS}

During the period of study, rainfall varied from 0.0 $\mathrm{mm}$ (Nov./01) to $299 \mathrm{~mm}$ in June/01; the average of the rainy period was $151.73 \mathrm{~mm}$ and the dry period $64.15 \mathrm{~mm}$. January was an atypical month, as the rainfall was $172.7 \mathrm{~mm}$ (Table 1).The abiotic variables and Trophic State Index from the studied months are shows in Table 1. Water transparency was higher at the periods, indicating that rain was not the factor that most influence this parameter. Total phosphorus was higher during the rainy season and the opposite was the case with the total nitrogen (Table 1).The reservoir was eutrophic to hypertrophic and the $\mathrm{pH}$ was alkaline during all period of study, varying from 8.22 to 9.04 (Table $1)$.

\section{Species Composition}

Forty-five taxa were identified in Carpina Reservoir from the following divisions: Cyanophyta, Chlorophyta and Bacillariophyta (flagellates were quantified but not identified). Chlorophyta presented highest diversity comprising 21 identified taxa. This group was represented by three orders: Chlorococcales (17 spp), Zygnematales (3spp) and Ulotrichales (1sp). Cyanophyta was the second group in diversity comprising 17 taxa from the orders Chroococcales, Nostocales and Oscillatoriales. Pennales (6spp.) was the most important order in Bacillariophyta which comprised 7 taxa.

\section{Subsurface and Bottom Density}

Total density varied from $1.49 \times 10^{6}$ org. $\mathrm{L}^{-1}$ (August 2001) to $9.72 \times 10^{6}$ org. $L^{-1}$ (March 2002) at the subsurface and from $9.06 \times 10^{5}$ org. $L^{-1}$ (April 2001) to $7.33 \times 10^{6}$ org. $L^{-1}$ (March 2002) at the bottom (Fig.1). It was also observed that subsurface and bottom densities were similar $(r=0.66)$. Phytoplanktonic densities presented a negative correlation with Secchi depth values $(r=-0.80$ e $r$ $=-0.84)$ at the subsurface and bottom, respectively. Cyanophyta presented highest density both at the subsurface and bottom and varied from $3.57 \times 10^{5} \mathrm{org} . \mathrm{L}^{-1}$ (April 2001) to $7.84 \times 10^{6}$ org. $L^{-1}$ (March 2002) (Figure 1a, b). As shown in Table 2, this group presented a negative correlation with Secchi depth values $(r=-0.80$ at the subsurface and $r=-0.90$ at the bottom). Flagellates presented a similar correlation pattern to Cyanophyta concerning water transparency $(r=$ -0.75 and $r=-0.64)$. Distribution patterns of Bacillariophyta were explained $(\mathrm{r}=0.64)$ by rainfall.

\section{Similarity}

Similarity of phytoplanktonic community between the subsurface and the bottom presented similar values from April/2001 and March/2002 (Table 3), varying from 0.49 (lower similarity in April/2001) to 0.60 (higher similarity in January/2002). Lowest similarities were observed in the highest rainfall periods (June, July and August), with the exception for April/2001 (Table 3). Cyanophyta was the most important division with the highest similarity value (0.60), comprising 15 taxa both at the subsurface and bottom.

\section{Specific Diversity and Equitability}

According to the diversity indexes phytoplanktonic community presented diversity values varying from 3.1 bits.ind $^{-1}$ (March/2002) to 4.3 bits.ind $^{-1}$ (June/2001) at the subsurface and from 3.3 bits.ind $^{-1}$ (March/2002) to 4.3 bits.ind $^{-1}$ (June 2001) (Table 3). Highest diversity occurred at the rainy period $\left(4.3\right.$ bits.ind $\left.^{-1}\right)$ in the month with highest rainfall (June/2001) both at the subsurface and the bottom. The diversity values 
observed in March/2002 could be explained by the high densities of Planktothrix agardhii Komárek (4.45 $\times 10^{6}$ org. $\left.1^{-1}\right)$, Cylindrospermopsis raciborskii (Wolz.) Seenayya et Subba-Raju (1.39x106 org.L${ }^{1}$ ), Komvophorum schmidlei (Jaaq.) Anagnostidis and Komárek (5.59 $\times 10^{5}$ org. $\left.\mathrm{L}^{-1}\right)$ and flagellates (6.68x $10^{5}$ org. $\left.\mathrm{L}^{-1}\right)$ at the subsurface and $C$. raciborskii $\left(9.15 \times 10^{5}\right.$ ogr. $\left.\mathrm{L}^{-1}\right), \quad$ Geitlerinema amphibium (Agardh ex Gomont) Anagnostidis (4.45 $10^{5}$ org. $\left.\mathrm{L}^{-1}\right), \quad$ Komvophorum schmidlei (4.08x $10^{5}$ org. $\left.\mathrm{L}^{-1}\right)$ e P. agardhii $\left(3.46 \times 10^{6}\right.$ org. $\left.\mathrm{L}^{-1}\right)$ at the bottom.
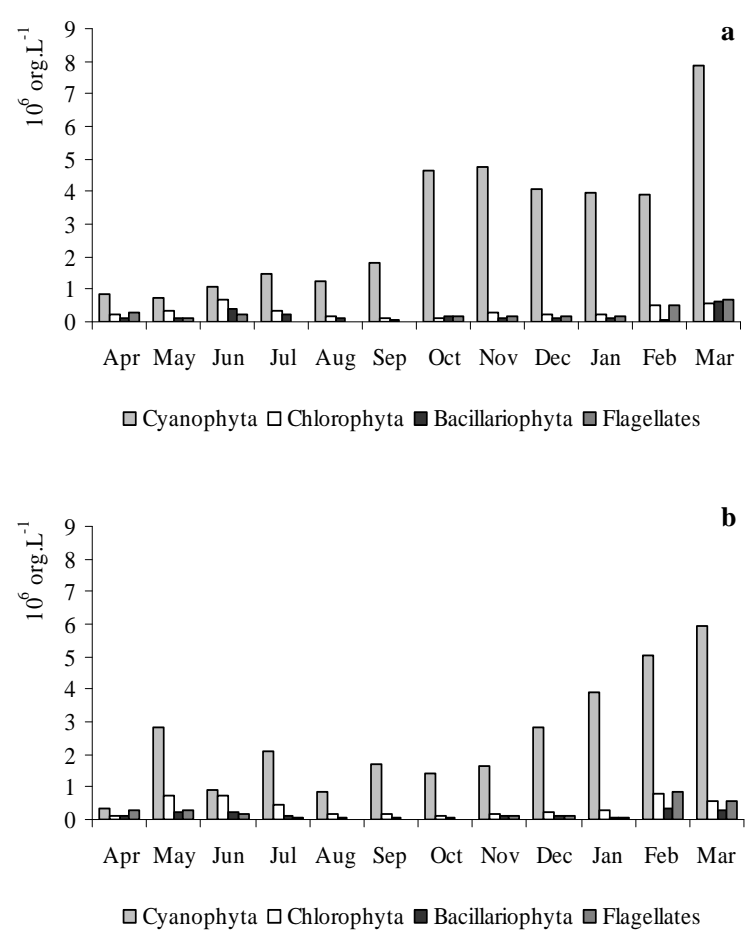

Figure 1 - Total densities of phytoplankton at the subsurface (a) and bottom (b) between April/2001 and March/2002 in the Carpina reservoir, Pernambuco, Brazil.

Phytoplanktonic community was equitable only in June/2001, both at the subsurface (0.51) and at the bottom (0.51). Equitability varied from 0.29 (March/2002) to 0.51 (June/2001), both at the subsurface and the bottom (Table 3) and was correlated to water transparency at both the depths ( $\mathrm{rs}=0.75$ and $\mathrm{rs}=0.77)$. A decreasing equitability pattern was observed from June/2001 to October/2001 at the subsurface. Equitability increased in November/2001 (0.47) and immediately started a new decrease up to March/2001. Sample analysis from the depth indicated the highest equitability value in June/2001 (0.51) without a continuous pattern during the rainy period. Equitability presented a continuous increasing pattern from September/2001 to November/2001. In the other months, this parameter presented an irregular pattern. A significant correlation of Cyanophyta with this parameter $(r s=-0.64)$.

\section{DISCUSSION}

Phytoplankton is quite diverse in the reservoirs due to the trophic degree at each environment. Diversity is generally low at oligotrophic environments due to low nutrient levels and the highest values occur at unstable environments.

Concerning species diversity, Carpina Reservoir presented a medium diversity, when compared to others reservoirs, as observed by Falcão et al. (2002); Giani and Pinto-Coelho (1986); Lopes et al., (2005) and Romo and Miracle, 1993). The Chlorophyta, followed by Cyanophyta and Bacillariophyta presented a high number of the species. These results agree who described for 
Falcão et al (2002) who observed that Chlorophyta as the best represented division at seven hydrographic basins in Pernambuco since they presented different trophic degrees. Chlorococcales was the most representative (81\%) order in the Carpina Reservoir. Theses results confirmed what was observed to different Brazilian eutrophic reservoirs Sant'Anna et al., 1989; Tucci, 1996; Ramírez, 1996 and Sant'Anna et al., 1997 at Garças Lake - SP. According to Huszar (1989), Cholorococcales was the group with highest species richness among chlorophyceans in the Brazilian lakes. This result was in agreement with Lewis (1978) who affirmed that Chlorococcales composition was a pantropical characteristic.

Cyanophyta was the second best represented group (17 identified taxa) corresponding to $38 \%$ of total phytoplanktonic taxa. This was in agreement with de Falcão et al. (2002) and also corroborated with the studies performed on reservoirs situated at the rural region of Pernambuco. According to the authors, Oscillatoriales and Chroococcales were more representative than Nostocales.

Bacillariophyta was the least representative group. During the study period, increasing of diatoms taxa was associated with the highest rainfall months. It was in agreement to Sommer (1987) who suggested that diatoms needed lower light demands than other algae, completing its cycle at the bottom, where light penetration was generally lower.

Density of the different groups in the phytoplanktonic community is related to several factors, as trophic levels, light, $\mathrm{pH}$ and grazing. Cyanophyta presented highest densities in Carpina Reservoir, likely influenced by alkaline $\mathrm{pH}$ of the area.

This was in agreement with Shapiro (1990) who suggested that Cyanophyta made use of the present $\mathrm{CO}_{2}$, even in low concentrations and $\mathrm{HCO}_{3}$ as a carbon source which preview capacity them to overcome eukaryotes. According to the author, low $\mathrm{pH}$ values increase grazing activity. Present results agreed with Tucci (1996), who recorded Cyanophyta contributing to the highest densities both at the rainy period (37\%) and at the dry period (38\%); density values corroborated with other studies in water supply (Dellamano-Oliveira et al., 2003; Calijuri et al., 2002 and Costa et al., 2006, who considered elevated phytoplankton densities $\left(9.69 \times 10^{6}\right.$ ind. $\left.\mathrm{L}^{-1}\right)$ to lentic environments in subtropical climate.

In water column mixing due to elevated pluviometric rainfall led to the highest specific/month diversity (June/2001) at the subsurface and at the bottom (4.3 bits.ind ${ }^{-1}$ ); as well as equitability (0.5), indicating a more equilibrated development on the phytoplanktonic community and on the individuals from each taxon.

Table 1- Mean rainfall values, Secchi disk, Photic zone (Zpho), Light attenuation coefficient (K) m, Trophic State Index, $\mathrm{pH}$, Total phosphorus and Total nitrogen during the study in the Carpina reservoir, Pernambuco, Brazil.

\begin{tabular}{|c|c|c|c|c|c|c|c|c|}
\hline Months & $\begin{array}{l}\text { Mean } \\
\text { rainfall } \\
(\mathrm{mm})\end{array}$ & $\begin{array}{l}\text { Secchi } \\
\text { disk } \\
(\mathbf{m})\end{array}$ & $\begin{array}{l}\text { Photic } \\
\text { zone } \\
\text { Zpho } \\
\text { (m) } \\
\end{array}$ & $\begin{array}{c}\text { Light } \\
\text { attenuation } \\
\text { coefficient } \\
(\mathbf{K})(\mathbf{m}) \\
\end{array}$ & $\begin{array}{l}\text { Trophic State Index } \\
\text { (IET) }\end{array}$ & pH & $\begin{array}{c}\text { PT } \\
\left(\mu \mathrm{g} . \mathrm{L}^{-1}\right)\end{array}$ & $\begin{array}{l}\text { NT } \\
\left(\mu g . L^{-1}\right)\end{array}$ \\
\hline Apr/01 & 78.5 & 1.1 & 2.97 & 1.55 & 58.62Eutrophic & 8.76 & - & - \\
\hline May/01 & 12.0 & 1.1 & 2.97 & 1.55 & 58.62Eutrophic & 8.69 & - & - \\
\hline Jun/01 & 299 & 1.3 & 3.51 & 1.31 & 56.30Eutrophic & 9.04 & - & - \\
\hline Jul/01 & 207.4 & 1.1 & 2.97 & 1.55 & 58.62Eutrophic & 8.66 & 143.83 & 52.79 \\
\hline Aug/01 & 120.0 & 1.2 & 3.24 & 1.42 & 57.40Eutrophic & 8.54 & - & - \\
\hline Sep/01 & 62.6 & 1.1 & 2.97 & 1.55 & 58.62Eutrophic & 8.93 & - & - \\
\hline Oct/01 & 78.0 & 1.0 & 2.70 & 1.70 & 60.00Eutrophic & 8.27 & - & - \\
\hline Nov/01 & 0.0 & 1.1 & 2.97 & 1.55 & 58.62Eutrophic & 8.43 & - & - \\
\hline Dec/01 & 21.6 & 1.0 & 2.70 & 1.70 & 60.00Eutrophic & 8.22 & 108.41 & 1279.77 \\
\hline $\mathrm{Jan} / 02$ & 172.7 & 0.9 & 2.43 & 1.89 & 61.51Hypertrophic & 8.76 & - & - \\
\hline Feb/02 & 50.0 & 0.8 & 2.16 & 2.13 & 63.21Hypertrophic & 9.02 & - & - \\
\hline Mar/02 & 193.5 & 0.7 & 1.89 & 2.43 & 65.10Hypertrophic & 8.93 & - & - \\
\hline
\end{tabular}


Table 2- Matrix correlation of total densities of algal groups at the subsurface and bottom in the Carpina reservoir, Pernambuco, Brazil.

\begin{tabular}{|c|c|c|c|c|c|c|c|c|c|c|}
\hline Cyano subs & 1.00 & & & & & & & & & \\
\hline Chlo subs & 0.16 & 1.00 & & & & & & & & \\
\hline Baci subs & 0.48 & 0.66 & 1.00 & & & & & & & \\
\hline Flagel subs & 0.68 & 0.63 & 0.61 & 1.00 & & & & & & \\
\hline Cyano bot & 0.69 & 0.39 & 0.38 & 0.72 & 1.00 & & & & & \\
\hline Chlo bot & -0.06 & $\mathbf{0 . 8 3}$ & 0.38 & 0.42 & 0.48 & 1.00 & & & & \\
\hline Baci bot & 0.22 & 0.83 & 0.45 & 0.76 & 0.64 & 0.87 & 1.00 & & & \\
\hline Flagel bot & 0.34 & 0.59 & 0.24 & 0.84 & 0.68 & 0.62 & 0.90 & 1.00 & & \\
\hline Rainfall & -0.05 & 0.53 & 0.64 & 0.13 & 0.02 & 0.35 & 0.17 & -0.09 & 1.00 & \\
\hline \multirow[t]{2}{*}{ Secchi } & -0.80 & -0.13 & -0.29 & -0.75 & -0.90 & -0.15 & -0.46 & -0.64 & 0.13 & 1.00 \\
\hline & $\begin{array}{l}\text { Cyano } \\
\text { subs }\end{array}$ & $\begin{array}{l}\text { Chlo } \\
\text { subs }\end{array}$ & $\begin{array}{l}\text { Baci } \\
\text { subs }\end{array}$ & $\begin{array}{l}\text { Flagel } \\
\text { subs }\end{array}$ & $\begin{array}{l}\text { Cyano } \\
\text { bot }\end{array}$ & $\begin{array}{l}\text { Chlo } \\
\text { bot }\end{array}$ & $\begin{array}{l}\text { Baci } \\
\text { bot }\end{array}$ & $\begin{array}{l}\text { Flagel } \\
\text { bot }\end{array}$ & Rainfall & Secchi \\
\hline
\end{tabular}

Table 3 - Secchi disk and mean rainfall values, Specific Diversity (bits.ind-1) and Equitability values at the subsurface and bottom and similarity of Sørensen between the depths in the Carpina reservoir, Pernambuco, Brazil.

\begin{tabular}{|c|c|c|c|c|c|c|c|c|c|c|c|c|}
\hline & apr/01 & may/01 & jun/01 & jul/01 & aug/01 & sep/01 & oct $/ 01$ & nov/01 & dec/01 & jan/02 & feb/02 & $\mathrm{mar} / 02$ \\
\hline $\begin{array}{l}\text { Mean } \\
\text { rainfall }\end{array}$ & 78.50 & 12.00 & 299.00 & 207.40 & 120.00 & 62.60 & 78.00 & 0.00 & 21.60 & 172.70 & 50.00 & 193.50 \\
\hline $\begin{array}{l}\text { Secchi } \\
\operatorname{disk}(m)\end{array}$ & 1.10 & 1.10 & 1.30 & 1.10 & 1.20 & 1.10 & 1.00 & 1.10 & 1.00 & 0.90 & 0.80 & 0.70 \\
\hline $\begin{array}{l}\text { Diversity } \\
\text { subsurface }\end{array}$ & 3.70 & 4.00 & 4.30 & 3.90 & 3.40 & 3.50 & 3.50 & 4.10 & 3.70 & 3.90 & 3.70 & 3.10 \\
\hline $\begin{array}{l}\text { Equitability } \\
\text { subsurface }\end{array}$ & 0.38 & 0.48 & 0.51 & 0.47 & 0.43 & 0.42 & 0.39 & 0.47 & 0.42 & 0.42 & 0.38 & 0.29 \\
\hline $\begin{array}{l}\text { Diversity } \\
\text { bottom }\end{array}$ & 3.50 & 4.10 & 4.30 & 3.50 & 3.50 & 3.50 & 3.40 & 3.80 & 3.80 & 3.60 & 3.90 & 3.30 \\
\hline $\begin{array}{l}\text { Equitability } \\
\text { bottom }\end{array}$ & 0.39 & 0.43 & 0.51 & 0.39 & 0.47 & 0.42 & 0.43 & 0.45 & 0.42 & 0.38 & 0.39 & 0.32 \\
\hline Similarity & 0.49 & 0.56 & 0.58 & 0.54 & 0.55 & 0.53 & 0.56 & 0.57 & 0.56 & 0.60 & 0.59 & 0.59 \\
\hline
\end{tabular}

The decrease in Secchi depth in the water from December/2001 to March/2002 was partly associated to the increase of densities in Cyanophyta. This indicated competitive advantages to Cyanophyta, once the high densities of Planktothrix agardhii Komárek decreased. Selfshading caused by Cyanophyta, which presented the highest densities, influenced the development of Chlorophyta negatively. According to HappeyWood (1998), self-shadings exerted by Cyanophyta excluded Chlorophyta due to the advantage of the first group concerning chromatic adaptation. Bicudo et al. (1999) affirmed that quality of sub aquatic light, water column stability separated light and nutrients spatially. The losses by sedimentations and the self-shadings of algae represent limiting environmental factors to chlorophyceans, especially to those non-mobile. Bacillariophyta presented a directly proportional relation between pluviometric/months rainfall and the densities of this group that made the first a regulator factor for the second. Rainfall causes an alocthonous input to the ecosystem as well as a higher mixture at the water column. Thus, these 
factors caused a ressuspension of the diatoms. Therefore, water column stability had a negative influence on the diatoms development. According to Sommer (1987), diatoms presented lesser light demand than other algae, growing better at the depth where light intensity was lower. The decrease of de $Z_{\text {mix }}$, indicated a high thermal stability and influenced the numerical density of these organisms, which favored their sedimentation and consequently, promoted the losses of silica to the deepest zones.

Concerning similarity, highest values of this index were related to the months with highest densities of Cyanophyta (January/2002, February/2002 and March/2002) at the surface and bottom. These densities caused a decrease in the Secchi depth values, approached the depth between these two regions and allowed algae to have a more uniform distribution at this extract. Besides, wind pulse had a positive action at the mixture of water in the close regions, as well as the capacity of Planktothrix agardhii (dominant taxon) to migrate at the water column. This was reinforced by Cyanophyta that presented $71.4 \%$ of its taxa common both to the subsurface and bottom in the month with the highest similarity value (January/2002). Similarity presented a modest increase in the month with highest rainfall (June/2001), which could be related to the high development of Chlorophyta caused by the mixture at the epilimnium.

Specific Diversity decreased with a direct relation to pluviometric indexes from June to October (2001). In the month with lowest rainfall (November/2001), another increase it was observed in the community diversity values. A decreasing pattern with an inverse relation to the densities of Cyanophyta was also observed during the dry period that suggested densities of this group as the main factor which influenced this index at the dry period.

Highest equitability value was observed in the highest pluviometric rainfall month (June/2001) and could be partly explained by the favorable conditions to Chlorophyta in this month due to high water mixture that favored a better development of their taxa. This was reflected in the increase of density of this group, which associated to the lowest densities of Cyanophyta making the number of individuals more uniform within its respective taxa. This agreed with Tucci (1996) who related highest equitability values of the community to the water mixture occurred at the rainy periods.

Decreasing equitability pattern of the community at the subsurface (November/2001) was caused by the increase of Cyanophyta densities, especially Planktothrix agardhii, promoting changes in the phytoplanktonic community organization and a reduction in the water transparency. These results were in agreement with Tucci (1996), who observed the lowest equitability values influenced by high densities of Microcystis at the superficial layers of a lake and Ramírez (1996) who attributed the lowest equitability values of the studied community to overcome the Microcystis. Ramírez and Bicudo (2002) suggested that in cases whose one or two species presented high densities, their regulation capacity prevail.

\section{RESUMO}

O objetivo deste trabalho foi o estudo da comunidade fitoplanctônica em ambiente limnético de Pernambuco, Brasil. As amostras foram coletadas de abril/2001 a março/2002. As amostras para análises abióticas foram coletadas na superfície da água e destinadas às análises bióticas foram coletadas na subsuperfície e no fundo, sendo fixadas com solução de lugol e quantificadas usando microscópio invertido. Equitatividade, índices de similaridade e diversidade foram calculados, bem como correlação entre as profundidades. 45 táxons foram identificados, pertencentes as Chlorophyta (21spp), Cyanophyta (17spp) e Bacillariophyta (7spp). Os flagelados foram apenas quantificados, mas não foram identificados. Cyanophyta apresentou a mais alta diversidade em ambas as profundidades e Planktothrix agardhii foi a espécie que apresentou a maior densidade. Diferenças significativas quanto às densidades não foram observadas entre subsuperfície e fundo. $\mathrm{O}$ reservatório encontra-se eutrofizado, sendo encontradas altas densidades de Cyanophyta durante todo o período de estudo.

\section{REFERENCES}

Ayres, M.; Ayres Jr., M.; Ayres, D. L. and Dos Santos, A. A. (2003), Software BioEstat, aplicações estatísticas nas áreas das ciências biomédicas - 
Versão 3.0. Belém: Sociedade Civil Mamirauá/ MCT/ CNPq.

Azevedo S. M. F. O. (1996), Toxic cyanobacteria and the Caruaru tragedy. Proc IV Symposium of Brazilian Society of Toxicology, p. 83.

Beyruth, Z. (2000), Periodic disturbances, trophic gradient and phytoplankton characteristics related to cyanobacterial growth in Guarapiranga Reservoir, São Paulo State, Brazil. Hydrobiologia, 424, 51-65.

Bicudo, C. E. M.; Ramírez, R. J. J.; Tucci, A. and Bicudo, D. C. (1999), Dinâmica de populações fitoplanctônicas em ambiente eutrofizado: O lago das Garças, São Paulo. In: Henry, R. (Ed.). Ecologia de Reservatórios: Estrutura, função e aspectos sociais. Botucatu: Fapesp/Fundibio, pp. 449-508.

Bittencourt-Oliveira, M. C and Molica, R. (2003), Cianobactéria invasora: aspectos moleculares e toxicológicos de Cylindrospermopsis raciborskii no Brasil. Biotecnologia: Ciência e Desenvolvimento, 30, 82-90.

Blancher, E. C. (1984), Zooplankton-trophic state relationship in some north and central Florida lakes. Hydrobiologia, 109, 251-63.

Bouvy, M.; Falcão, D.; Marinho, M.; Pagano, M. and Moura, A. (2000), Occurence of Cylindrospermopsis (Cyanobacteria) in 39 Brazilian tropical reservoirs during the 1998 drought. Aquatic Microbial Ecology, 15, 122-164.

Bouvy, M.; Molica, R.; Oliveira, S.; Marinho, M. and Beker, B. (2001), Dynamics of a toxic cyanobacterial bloom (Cylindrospermopsis raciborskii) in a shallow Reservoir in the semi-arid region of northest Brazil. Aquatic Microbiology Ecology, 20, 285-297.

Bouvy, M. A.; Nascimento, S.; Molica, R. J. R.; Ferreira, A.; Huszar, V. and Azevedo, S. M. F. O. (2003), Limnological features in Tapacurá reservoir (northeast Brazil) during a severe drought. Hydrobiologia, 493, 115-130.

Calijuri, M. C., Deberdt, G. L. B. and Minoti, R. T. (1999), A produtividade primária pelo fitoplâncton na represa de Salto Grande (Americana - SP). In: Henry, R. (Ed.) Ecologia de Reservatórios: Estrutura, função $e$ aspectos sociais. Botucatu: Fapesp/Fundibio, pp. 409-448.

Calijuri, C. M. and Dos Santos, A. C. A. (2001), Temporal variations in phytoplankton primary production in a tropical reservoir (Barra Bonita, SP, Brazil). Hydrobiologia, 445, 11-26.

Calijuri, M. C.; Dos Santos, A. C. A. and Jati, S. (2002), Temporal changes in the phytoplankton community structure in a tropical and eutrophic reservoir (Barra Bonita, SP-Brazil). Journal of Plankton Research, 24, 617-634.

Carlson, R. E. (1977), A trophic state index for lakes, Contribution $\mathrm{N}^{\circ} 141$, Limnological Research Center, University of Minnesota, Minneapolis, 17p.
Chellapa, N. T. (1990), Phytoplankton species composition, chlorophyll biomass, and primary production of the Jundiaí Reservoir (northeastern Brazil) before and after eutrophization. Acta Hydrobiologica, 32, 75-91.

Chellapa, N. T.; Bezerra, T. A.; Costa W. T. T. and Melo, S. C. (1998), Physiological ecology of cyanophycean population from impounded freshwater aquatic ecosystem, Barragem Gargalheiras, Rio Grande do Norte State. In: IV Simpósio de Ecossistemas Brasileiros. Anais... Águas de Lindóia, SP, Brasil, II, pp. 372-380.

Chellapa, N. T. and Costa, M. A. M. (2003), Dominant and co-existing species of Cyanobacteria from a Eutrophicated reservoir of Rio Grande do Norte State, Brazil. Acta Oecologica, 24, 4-10.

Costa, I. A. S.; Azevedo, S. M. F. O.; Senna, P. A. C.; Bernardo, R.R., Costa, S.M. and Chellapa, N. T. (2006), Occurrence of toxin-producing Cyanobacteria blooms in a Brazilian Semiarid reservoir. Brazilian Journal of Biology, 66, 211-219.

De Bernardi, R. (1984), Methods for the estimation of zooplankton abundance. In: Downing and Rigler, A. (Ed.). Manual on Methods for the assessment of secondary Productivity in Freshwaters. 2.ed. Oxford: Blackwell Sci. Publ, pp. 59-63 (I.B.P. Hand. 17).

Dellamano-Oliveira, J. M.; Senna, P.A.C.; Taniguchi, G. M. (2003), Limnological Characteristics and Seasonal Changes in Density and Diversity of the Phytoplanktonic Community at the Caço Pond, Maranhão State, Brazil. Brazilian Archives of Biology and Technology, 46, 641-651.

Falcão, D. P. M.; Moura, A. N.; Pires, A. N.; Bouvy, A. H. B.; Marinho, M.; Ferraz, A. C. N. and Silva, A. M. (2002), Diversidade de microalgas planctônicas de mananciais localizados nas zonas fitogeográficas: Mata, Agreste e Sertão do Estado de Pernambuco. In: Tabarelli, M. and Silva, A. M. (Eds.). Diagnóstico da biodiversidade de Pernambuco. Recife: Secretaria de Ciência, Tecnologia e Meio Ambiente, 1, pp. 63-77.

Figueredo, C. C. and Giani, A. (2001), Seasonal variation in the diversity and species richness of phytoplankton in a tropical eutrophic reservoir. Hydrobiologia, 445, 165-174.

Giani, A. and Pinto-Coelho, R. M. (1986), Contribuição ao conhecimento das algas fitoplanctônicas do reservatório do Paranoá; Brasília, Brasil: Chlorophyta, Euglenophyta, Pyrrophyta e Schizophyta. Revista Brasileira de Botânica, 9, 4562.

Happey-Wood, C. M. (1988), Ecology of freshwater planktonic green algae. In: Sandgreen, C. D. (Ed.). Growt and reproductive strategies of freshwater phytoplankton. Cambridge: Cambridge University Press, pp. 175-226. 
Harris, G. P. (1986), Phytoplankton ecology: structure, function and fluctuation. London: Chapman and Hall. 384 pp.

Huszar, V. L. M. (1989), Considerações sobre o fitoplâncton da Lagoa de Juturnaíba, Araruama, Rio de Janeiro, Brasil. Revista Brasileira de Biologia, 49, 107-23.

Jochimsen, E. M.; Carmichael, W. W. J.; Cardo, D. M.; Cookson, S. T.; Holmes, C. E. M.; Antunes, B. C.; Melo Filho, D. A.; Lyra, T. M.; Barreto, V. S. T.; Azevedo, S. M. F. O. and Jarvis, W. R. (1998), Liver failure and death after exposure to microcystins at a hemodialysis center in Brazil. New England Journal Medicine, 338, 873-878.

Kalff, J. and Knoechel, R. (1978), Phytoplancton and their dynamics in oligotrophic and eutrophic lakes. AnnualReview of Ecology and Systematics, 9, 475-95.

Komárek, J. (1983), Das Phytoplankton des Süsswasser Systematik und Biologie. 7. Teil: Chlorophyceae (Grünalgen) Ordnung: Chlorococcales. In: Elster. H.-J. and Ohle, W. (Eds): Die Binnengewässer. Begründet von August Thienemann, Stutgart.

Komárek, J. and Anagnostidis, K. (1999), Cyanoprokaryota. 1. Teil: Chroococcales. In: Ettl, H., Gärtner, G. and Heynig, H. and Mollenhauer, D. (eds): Süsswasser von Mitteleuropa. Gustav Fischer, Stutgart.

Komárek, J. and Anagnostidis, K. (2005), Cyanoprokaryota 2. Teil: Oscillatoriales. Süsswasser von Mitteleuropa. B. Bridel G. Gastner, L. Krienitz, M. Schargerl (Hrs.) 19/2. Elsevier. 759p.

Lewis, W. M. Jr. (1978), Analysis of succession in a tropical phytoplankton community and a new measure of succession rate. American Naturalist, 112, 401-414.

Lopes, M. R.; Bicudo, C. E. M. and Ferragut, M. C. (2005), Short term spatial and temporal variations of phytoplankton in a shallow tropical oligotrophic reservoir, southeast Brazil. Hydrobiologia, 542, 235247.

Margalef, R. (1983), Limnologia. Omega, S. A., Barcelona.

Marinho, M. M. and Huzsar, V. L. M. (2002), Nutrient availability and physical conditions as controlling factors of phytoplankton composition and biomass in a tropical reservoir (Southeastern Brazil). Archiv Hydrobiologie, 153, 443-468.

Poole, H. H. and Atkins, W. R. G. (1929), Photoelectric measurements of submarine illumination through out the year. Journal Marine Biological Association, 16, 297-324

Ramírez, J. J. (1996), Variações espacial vertical $e$ nictemeral da estrutura da comunidade fitoplanctônica e variáveis ambientais em quatro dias de amostragem de diferentes épocas do ano no Lago das Garças, São Paulo. Tese de Doutorado, Universidade de São Paulo, São Paulo, Brasil.
Ramírez, J. J. and Bicudo, C. E. M. (2002), Variation of climatic and physical co-determinants of phytoplankton community in four nictemeral sampling days in a shallow tropical reservoir, Southeastern Brazil. Brazilian Journal of Biology, 62, $1-14$.

Reynolds, C. S. (1984), The ecology of freshwater phytoplankton. Cambridge: Cambridge University Press. 384pp.

Reynolds, C. S. (1997), Vegetation processes in the pelagic: a model for ecosystem theory. Germany: Ecology Institute. 371pp.

Romo, S. and Miracle, M.R. (1993), Long-term periodicity of Planktothrix agardhii, Pseudanabaena galeata and Geitlerinema sp. In a shallow hypertrophic lagoon, the Albufera of Valencia (Spain). Arch. Hydrobiology, 126, 469-486.

Round, F. E.; Crawford, R. M. and Mann, D. G (1990), The Diatoms. Biological and morphology of the genera. Cambridge. pp. 747

Sant'Anna, C. L. (1984), Chlorococcales (Chlorophyceae) do Estado de São Paulo, Brasil. São Paulo, p. 348.

Sant'Anna, C. L.; Azevedo, M. T. P. and Sormus, L. (1989), Fitoplâncton do Lago das Garças, Parque Estadual das Fontes do Ipiranga, São Paulo, SP, Brasil: estudo taxonômico e aspectos ecológicos. Hoehnea, 16, 89-131.

Sant'Anna, C. L.; Sormus, L.; Tucci, A. and Azevedo, M. T. P. (1997), Variação sazonal do fitoplâncton do lago das Garças, SP. Hoehnea, 24, 67-86.

Shannon, C. E. (1948), A mathematical theory of communication. Bulletin of System Technology Journal, 27, 379.

Shapiro, J. (1990), Current beliefs regarding dominance by blue-green: the case for the importance of $\mathrm{CO}_{2}$ and $\mathrm{pH}$. Verhandlunger der Internationalen Vereinigung für Theoretische und Angewandte Limnology, 24, 3854.

Sommer, U. (1987), Factors controlling the seasonal variation in phytoplankton species composition - a case study for a deep, nutrient rich lake program. Phycology Research, 5, 110-73.

Sommer, U. (1989), Plankton ecology; succession in plankton communities. Berlin: Springer Verlag. 364 pp.

Sørensen, T. A. (1948), A method for estabilishing groups of equal amplitud in plant Sociology based on similarity of species content and its aplication to analisis of the vegetation on Danish commons. Biologiske Skrifter, 5, 1-34.

Tucci, A. (1996), Estrutura e dinâmica da comunidade fitoplanctônica numa lagoa eutrófica, São Paulo, SP, Brasil, a curtos intervalos de tempo: comparação entre épocas de chuva e seca. Dissertação (Mestrado), Universidade Estadual Paulista, Rio Claro, Brazil. 
Utermöhl, H. (1958), Zur Vervollkommung der quantitativen Phytoplanktonmethodik. Mitteilungen der internationalen vereinigung für theoretische und angewandte Limnologie, 9, 1-38.

Valderrama, G.C. (1981), The simultaneous analysis of total nitrogen and total phosphorus in natural waters. Marine Chemistry, 10, 109-122.

Received: August, 2005; Revised: May 08, 2006; Accepted: March 14, 2007. 